\title{
An overview of nutritional and anti nutritional factors in green leafy vegetables
}

\begin{abstract}
Vegetables play important role in food and nutritional security. Particularly, green leafy vegetables are considered as exceptional source for vitamins, minerals and phenolic compounds. Mineral nutrients like iron and calcium are high in leafy vegetables than staple food grains. Also, leafy vegetables are the only natural sources of folic acid, which are considerably high in leaves of Moringa oleifera plants as compared to other leafy and non-leafy vegetables. This paper reviewed nutritional and anti nutritional factors in some important common green leafy vegetables. The type and composition of nutritional and anti nutritional factors vary among genera and species of different edible leafy vegetables plants. Anti nutritional factors are chemical compounds in plant tissues, which deter the absorption of nutrients in humans. Their effects can be direct or indirect and ranges from minor reaction to death. Major anti nutritional factors such as nitrates, phytates, tannins, oxalates and cyanogenic glycosides have been implicated in various health-related issues. Different processing methods such as cooking and blanching can reduce the contents of anti-nutritional factors. This paper also discussed in brief the various analytical methods for the determination of the various nutritional and anti-nutritional factors in some green leafy vegetables.
\end{abstract}

Volume I Issue 2 - 2017

\author{
Hemmige Natesh N,Abbey L,Asiedu SK \\ Department of Plant, Food, and Environmental Sciences, \\ Dalhousie University, Canada
}

\begin{abstract}
Correspondence: Hemmige Natesh N, Faculty of Agriculture, Department of Plant, Food, and Environmental Sciences, Dalhousie University, PO Box 550, Truro B2N 5E3, Nova Scotia, Canada, Email nishchitha.natesh@gmail.com
\end{abstract}

Received: October 06, 2017| Published: November 17, 2017

Keywords: green leafy vegetables, nutritional factors, anti nutritional factors

\section{Abbreviations: RUBISCO, ribulose-1,5-bisphosphate carboxylase/oxygenase; LNA, $\alpha$-linolenic acid; WHO, world health organization; SDF, soluble dietary fiber; IDF, insoluble dietary fiber; USDA, us department of agriculture}

\section{Introduction}

Generally, vegetables are widely designated as "protective foods" in human diet due to their varied health benefits attributable to the richness in vitamins, essential fatty acids, minerals, amino acids and dietary fiber ${ }^{1}$ and various essential bioactive compounds. ${ }^{2}$ These include health-promoting plant secondary metabolites composed of antioxidants and phenolic compounds. It is well acknowledged that to meet recommended daily allowance of nutrition, the World Health Organization (WHO) recommendation at least $400 \mathrm{~g}$ of fruit and non-starchy vegetables (WHO, 2013) is used. The dietary guidelines for Americans recommend five servings of vegetables per day based on an intake of 2000 calories (HHS/USDA, 2015). It is also recommended that one of the five servings of vegetables should be green leafy vegetables. Nutritionists and dieticians are of the opinion that people should diversify their diets as no single vegetable meets all the nutritional requirements necessary for good health and wellbeing. ${ }^{3}$ Hence in today's agri-food systems, more emphasize is given to crop diversification with the intention of fulfilling human nutritional requirements, and to reduce the pressure on cereal production. ${ }^{4}$ Globally, crop diversity and nutritional value of vegetable crops are of special significance for improving food and nutrition security. ${ }^{5}$ Plants are major sources of numerous bioactive compounds collectively termed as phytochemicals, which are reported to be key to good health. ${ }^{2}$ Researchers have shown that the composition of phytochemicals is very distinctive and varies widely amongst plants. ${ }^{6}$ For instance, vegetables that belong to the Alliaceae family (e.g., onions, garlic, shallots, leek, Welsh onion and chives) are characterized by thiosulfides and flavonoids. Cruciferous vegetables that belong to the Brassicaceae family (e.g., cabbage, cauliflower, kale and broccoli) contain high sources of glucosinolates, and those that belong to Cucurbitaceae family (e.g., squash, pumpkin, cucumber, melon and bitter gourd) are rich in carotenoids and tocopherols. ${ }^{2}$ However, the compositions of these phytochemicals have been documented to be affected by factors such as genotypic characteristics, climatic conditions, edaphic factors and management practices. ${ }^{7-10}$ For instance, it was shown that for the same plant species, the mineral nutrients content and total phenolic compounds and antioxidants can be altered by the application of different sources of nutrients..$^{7-11}$

It is worth noting that while there are many groups of chemical compounds that have health benefits, others can be very toxic and fatal to humans when consumed. As such phytochemicals can be broadly classified as nutritional (e.g., essential fatty acids, proteins, vitamins, minerals and phenolic compounds) and anti-nutritional (e.g., oxalates, tannins, nitrate) chemical compounds. ${ }^{12}$ It is important for consumers and researchers to understand the importance of these chemicals and their impacts on human health and available methods for their assessments. This paper aims at reviewing the common phytochemicals in green leafy vegetables grown in various geographic locations of the world. The health-promoting phytochemicals will be referred to as nutritional factors and the health-inhibiting or toxic phytochemicals will be referred to as anti-nutritional factors. The importance of these phytochemicals will be highlighted to reflect their beneficial or toxicity and/or inhibitory effects on human health and wellbeing. Additionally, a brief description will be made on methods for determining the compositions of these phytochemicals in green leafy vegetables.

\section{Nutritional factors in green leafy vegetables}

Proteins: Proteins are large and complex molecules composed of various compositions of amino acids. Proteins play critical roles in 
cellular functions, structure and regulations of metabolic activities in all living organisms. Hence, proteins have primary importance in the daily diets of consumers. Green leafy vegetables are the richest and cheapest sources of proteins. This is because of their ability to synthesize and accumulative amino acids with the help of abundant source of sunlight, water, oxygen and nitrogen which is readily available in the atmosphere. ${ }^{13}$ About $50 \%$ of total leaf cell protein is dominated by ribulose-1,5-bisphosphate carboxylase/oxygenase (RUBISCO), which can be found in leaf chloroplasts. It plays a vital role in the fixation of atmospheric carbon during photosynthesis. ${ }^{14}$ RUBISCO is a similar protein found in all green leafy vegetables with few changes in amino acid groups from species to species. Recent evidence showed that green leafy vegetables such as spinach (Spinacia oleracea), broccoli (Brassica oleracea var. Italic) and duckweed (Lemna perpusilla) provide all the essential amino acids that meet the FAO nutrition standards. ${ }^{15}$ Evidence showed that apart from lower methionine content, cassava (Manihot esculenta) leaves consumed as green leafy vegetable has amino acids profile comparable with pulse and dairy products. ${ }^{16}$ It has been found that some of the African leafy vegetables such as green leaves of septic weed (Senna occidentalis) and cassava both have $7 \mathrm{~g}$ protein/100 g of fresh weight. This is higher than that of exotic leafy vegetables such as Brassica oleracea subsp. Capitate with a protein content of $1 \mathrm{~g} / 100 \mathrm{~g}$ of fresh weight. ${ }^{12}$ However, protein content in African leafy vegetables cannot be compared with legume proteins such as white lupines (Lupinus albus), which has $11.5 \mathrm{~g}$ protein/100g of fresh weight. ${ }^{17}$ The amount of protein content in leafy vegetables can vary with farming practices and prevailing environmental conditions. ${ }^{18}$ Bioavailability of protein in leafy vegetables is typically influenced by thermal processing, which inactivates heat-labile anti-nutritional factors such as protease inhibitors, lectins, thiaminases and goitrogens but enhances digestibility of proteins and starch. $^{19}$ Total protein is determined by evaluating total $\mathrm{N}$ using the Kjedahl method and multiplying the $\mathrm{N}$ value by 6.25 as described by Association of the Official Analytical Chemists. ${ }^{20}$

Dietary fiber: Dietary fiber is the constituent of plant cell wall (MacDougall, 1995). Dietary fiber is classified as soluble dietary fiber (SDF) and insoluble dietary fiber (IDF), which is collectively termed as total dietary fiber (TDF). Green leafy vegetables have been traditionally recognized as good sources of dietary fiber. ${ }^{21}$ Literature information showed that Indian Green leafy vegetables such as basella (Basella rubra), fenugreek (Trigonella foenum graecum), hibiscus (Hibiscus cannabinus), coriander (Coriandrum sativum), cabbage (Brassica oleracea) and spinach (Spinacia oleracea) are good sources of soluble dietary fiber content. Consumption of higher levels of vegetable fiber resulted in reduced risk of cardiovascular diseases and possibly, colon cancer. ${ }^{22}$ It was more significant in resolving the problem of constipation, diabetes, diverticulosis and obesity. ${ }^{23-25}$ The amount of total dietary fiber in green leafy vegetables can vary with different plant variety of the same species, agro-climatic conditions, stages of maturity and type and rate of fertilizer applications. Estimation of DF in GLV can be performed by using lyophilized powder and its fractions by enzymatic or gravimetric methods of AOAC.

Vitamins: Green leafy vegetables are abundant sources for $\beta$-carotene. In leaves, vitamin $A$ is present in the form of provitamin $A$ carotenoids such as $\beta$-carotene (ca. 25-30\%), $\alpha$-carotene, $\gamma$-carotene, $\beta$-cryptoxanthin and non-provitamin A carotenoids lutein (ca. 45\%), violaxanthin (ca. 15\%) and neoxanthin (ca. 15\%), ${ }^{26}$ the content of vitamin A is expressed in retinol equivalents (RE) with one (1) RE being equivalent to $6 \mu \mathrm{g}$ of $\beta$-carotene and $12 \mu \mathrm{g}$ of the other pro vitamin carotenoids. The recommended daily allowance (RDA) for vitamin A is also expressed in RE but recently, the U.S. Institute of Medicine has replaced RE with the term "retinol activity equivalent" (RAE; IOM, 2001). The Institute of Medicine dietary reference intake recommended 900 and $700 \mu \mathrm{g}$ RAE of vitamin A for an adult male and female, respectively. ${ }^{27}$ Increasing the consumption of green leafy vegetables that are widely available in developing countries help in combating prevailing vitamin A deficiency in regions where pharmaceutical supplements and vitamin A fortified foods are limited. ${ }^{28}$ Processing techniques such as cooking, boiling, and steaming have significant influence on availability of carotenoids in green leafy vegetables. ${ }^{29}$ A study conducted on 30 commonly used green leafy vegetables for nutritional purposes confirm the presence of good amount of lutein ${ }^{30}$ and richness in various vitamins. For instance, any species of Amaranths are excellent source of vitamin C. ${ }^{31}$ Furthermore, comparisons can be made on vitamins distribution among seeds and leafy plants. For instance, data obtained from USDA national nutrient database ${ }^{15}$ clearly shows that vitamin A and K1 (Phylloquinone) in leafy vegetables are exceptionally high for kale and spinach than the cereals and pulses. In addition, cereals and pulses are devoid of vitamin $\mathrm{C}$ whereas, leafy vegetables are the potential sources of vitamin C with good amount in kale $(1014 \mathrm{mg} / 100 \mathrm{~g})$. Vitamin $\mathrm{E}$ in duck weed $(45.7 \mathrm{mg} / 100 \mathrm{~g})$ is high among many common leafy vegetables and seeds. However, vitamin B5 in cereals and pulses are higher than spinach and kale but not in duck weed $(2.1 \mathrm{mg} / 100 \mathrm{~g})$. Foliate is a water-soluble compound, which belongs to vitamin B group. Deficiency of folic acid has severe metabolic and clinical consequences..$^{32}$ Plants are the major source of foliates for humans especially, green leafy vegetables. ${ }^{33}$ Cereal grains and tuber based staple diet are very low in foliate, which can be improved by the addition of green leafy vegetables. Leaves of colocasia (Colocasia esculenta) are used as an excellent source of foliate in the Indian diet. However, it is noticed that about $50 \%$ or more of foliate in food is found to be destroyed during cooking. This is mainly attributed to prolonged heating of vegetables in a large volume of water. Hence, it is advisable to consume the water used during the cooking of vegetables. ${ }^{34}$ A research study reported that5-formyl-5,6,7,8-tetrahydrofolic acid $(502.1 \mu \mathrm{g} / 100 \mathrm{~g}$ dry weight) and 5,6,7,8-tetrahydrofolic acid $(223.9 \mu \mathrm{g} / 100 \mathrm{~g}$ dry weight) are the dominant forms of foliate present in Moringa oleifera. Moringais known to be a significant source of foliate with higher bioavailability compared to other vegetables. ${ }^{35}$ High-performance liquid chromatography i.e. HPLC-DAD-MS/ MS based method developed by Santos et al. ${ }^{36}$ allows a simple and sequential extraction and monitoring of several free forms of water soluble vitamins (vitamins C, B1, B2, B3, B5, B6 and B9) and fatsoluble vitamins (pro-vitamin $\mathrm{A}$ and vitamin $\mathrm{E}$ ) present in raw green leafy vegetables Table 1.

Minerals: WHO (1996) stated that the "overall malnutrition must no longer be considered without reference to micronutrient status, as the two are inextricably linked. Attempting to improve proteinenergy status without addressing micronutrient deficiencies will not result in optimal growth and function". ${ }^{37}$ Metal ions are important to the normal functioning and wellbeing of humankind as they serve as cofactors in enzymatic reactions, and maintain protein structures. Iron deficiency in women and children lead to the development of anemia. ${ }^{38}$ Zinc deficiency results in impaired gastrointestinal and immune functions. ${ }^{39}$ A comparative mineral profile for seeds and green leaves are presented in Table 2. The data shows that green 
leafy vegetables are good sources of mineral nutrients. For instance, spinach has highest amount of calcium $(1036 \mathrm{mg} / 100 \mathrm{~g})$, magnesium $(827 \mathrm{mg} / 100 \mathrm{~g})$, iron $(28.4 \mathrm{mg} / 100 \mathrm{~g})$ and sodium $(827 \mathrm{mg} / 100 \mathrm{~g})$ whereas duck weed is high in zinc $(15 \mathrm{mg} / 100 \mathrm{~g})$. However, soy seed also has considerable amount of calcium $(195 \mathrm{mg} / 100 \mathrm{~g})$, iron $(6 \mathrm{mg} / 100 \mathrm{~g})$, magnesium $(407 \mathrm{mg} / 100 \mathrm{~g})$, phosphorus $(469 \mathrm{mg} / 100 \mathrm{~g})$ and potassium $(2387 \mathrm{mg} / 100 \mathrm{~g})$, sodium $(12.3 \mathrm{mg} / 100 \mathrm{~g})$ and zinc $(3.7 \mathrm{mg} / 100 \mathrm{~g})$ when compared to all the seeds but comparatively higher in the leafy vegetables. The absorption of mineral nutrients is adversely affected by the presence of inhibitors like oxalate and phytates and many other anti nutritional factors. ${ }^{40}$ Minerals have greater stability during food processing as compared to vitamins and proteins. ${ }^{41}$ But mineral profiles in green leafy vegetables are highly dependent on application of external synthetic fertilizer or organic soil amendments. Minerals in leafy vegetables can be determined by atomic absorption spectrophotometry (AAS) method, ${ }^{42}$ inductively coupled plasma optical emission spectroscopy (ICP-OES). ${ }^{31}$

Table I Vitamin compositions for some seed and leafy vegetables ${ }^{a}$

\begin{tabular}{lllllllll}
\hline & \multicolumn{7}{l}{ Seed } & \multicolumn{7}{c}{ Leaf } \\
\hline Vitamins concentrations $^{\mathrm{b}}$ & Wheat & Corn & Rice & Soy & Lentil & Kale & Spinach & Duck-Weed \\
\hline Vitamin A, IU & 9 & 167 & 0 & 114 & 68 & 130,000 & 85,500 & 77,900 \\
Vitamin BI, mg & 0.4 & 0.2 & 0.2 & 0.6 & 0.6 & 0.9 & 0.9 & 1.1 \\
Vitamin B2, mg & 0.2 & 0.1 & 0 & 1.1 & 1.3 & 0.9 & 1.8 & 2.8 \\
Vitamin B5, mg & 1 & 0.5 & 1.5 & 1.5 & 0.4 & 0.9 & 0.9 & 2.1 \\
Vitamin B6, mg & 0.3 & 0.3 & 0.8 & 0.5 & 0.5 & 2.5 & 1.8 & 1 \\
Vitamin C, mg & 0 & 0 & 0 & 0 & 2 & 1014 & 256 & 94 \\
Vitamin E, mg & 0.8 & 0.3 & 0.2 & 1.8 & ND & 9.3 & 18.2 & 45.7 \\
Vitamin KI, mg & 1.9 & 0.2 & 0 & 67 & ND & 6900 & 4400 & 51 \\
\hline
\end{tabular}

aSource: (Edelman and Colt, 2016). "Derived from the USDA National Nutrient Database (http://nutritiondata.self.com) for: wheat (Triticum aestivum) flour, whole grain; corn (Zea mays) flour, whole grain, yellow; rice (Oryza sativa) flour, white, un enriched; soy (Glycine max) flour, full-fat, raw; chick pea (Cicer arietinum), mature seeds, raw; lentil(Lens culinaris), pink, raw; spinach (Spinacia oleracea), raw; broccoli(Brassica oleracea var. italica), raw; kale (Brassica oleracea var. sabellica), raw. Data for duckweed (Lemnoideae) determined by Eurofins USA for a local Israeli isolate of dried, raw,Wolffia sp"; b values are per I00g sample.All samples are normalized at $10 \%$ moisture; ND, indicates not determine.

Table 2 Mineral compositions of some seed and green leafy vegetables ${ }^{2}$

\begin{tabular}{lllllllll}
\hline & \multicolumn{1}{l}{ Seed } & \multicolumn{7}{c}{ Leaf } \\
\hline Mineral concentration $^{\mathrm{b}}$ & Wheat & Corn & Rice & Soy & Lentil & Kale & Spinach & Duck-weed \\
\hline Calcium (mg) & 34 & 6.4 & 10 & 195 & 34 & 846 & 1036 & 607 \\
Iron (mg) & 3.8 & 2.2 & 0.4 & 6 & 6.4 & 8.3 & 28.4 & 25.7 \\
Magnesium (mg) & 120 & 85 & 36 & 407 & 46 & 265 & 827 & 231 \\
Phosphorus (mg) & 332 & 250 & 100 & 469 & 276 & 519 & 513 & 1741 \\
Potassium (mg) & 405 & 289 & 78 & 2387 & 664 & 2769 & 5840 & 5319 \\
Sodium (mg) & 3.1 & 4.6 & 0 & 12.3 & 5.9 & 214 & 827 & 132 \\
Zinc (mg) & 3 & 1.6 & 0.8 & 3.7 & 3.2 & 3.2 & 5.5 & 15 \\
\hline
\end{tabular}

aSource: (Edelman and Colt, 2016)."Derived from the USDA National Nutrient Database (http://nutritiondata.self.com) for:Wheat flour, whole grain; corn flour, whole grain, yellow; rice flour, white, un enriched; soy flour, full-fat, raw; chick pea, mature seeds, raw; lentil, pink, raw; spinach, raw; broccoli, raw; kale, raw. Data for duckweed determined by Eurofins USA for a local Israeli isolate of dried, raw, Wolffia sp"; b values are per 100g sample. All samples are normalized to I0\% moisture.

Essential fatty acids: Omega-3 fatty acids are important for normal growth and development, and play vital role in the prevention and treatment of coronary artery diseases, hypertension, diabetes, arthritis, cancer and other inflammatory and autoimmune disorders..$^{43}$ $\alpha$-linolenic acid, the precursor of omega-3 fatty acid has been found in green leafy vegetables with beneficial effects on health. ${ }^{44}$ It is known that essential fatty acids help to control various chronic diseases. ${ }^{44}$ Evidence shows that omega-3 fatty acids is relatively high in wild plants than in cultivated vegetables. ${ }^{45,46}$ For instance, the US Department of Agriculture (USDA) and other studies have reported that purslane (Portulaca oleracea), a wild plant and weed in most cases, is a good non-aquatic source of $\alpha$-linolenic acid with $4 \mathrm{mg} / \mathrm{g}$ fresh weight. The same study also reported the presence of $\alpha$-linolenic acid in other leafy green vegetables such as $1.7 \mathrm{mg} /$ gin spinach, $1.1 \mathrm{mg} / \mathrm{g}$ in mustard greens, $0.7 \mathrm{mg} / \mathrm{g}$ in red leaf lettuce and $0.6 \mathrm{mg} / \mathrm{g}$ in butter crunch lettuce. ${ }^{44}$ Fatty acids in leaves can be determined by gas chromatography. ${ }^{1}$

\section{Anti nutritional factors in green leafy vegetables}

Undesirable chemical substances referred to as anti nutrients are 
abundant in both cultivated and wild plant species. ${ }^{47}$ These antinutrients are also referred to as "Allelochemicals". ${ }^{48}$ The quantity and the distribution of these chemical compounds vary with plant genera and species. According to Cheek and Shull, ${ }^{49}$ being an anti nutritional factor is not an intrinsic characteristic of a compound but depends on the digestive process of the ingesting animal. The level of adversity is largely dependent on the diet pattern and method of processing involved before the consumption of the specific plant food. The individual compounds and their impact on human diet are described below. Some of the anti nutrients commonly found in leafy vegetables are nitrates, oxalates, tannins, phytates and cyanogenic glycosides.

Nitrate: Nitrate is one of the important and natural compounds found in vegetables, and is responsible for characterizing vegetable quality. Typically, nitrate concentration in leafy vegetables is found higher than other groups of vegetables such as root and fruits vegetables. ${ }^{50}$ Agronomic (practices such as the amount, timing and form of $\mathrm{N}$ fertilizer, and environmental and genetic factors can significantly influence the levels of nitrate in raw green leafy vegetables. ${ }^{51}$ A study conducted on 10 leafy vegetables harvested at two different light intensities (i.e. 200 and $400 \mu \mathrm{mol} \mathrm{m}-2 \mathrm{~s}-1$ ) showed higher nitrate accumulation when harvested at low light intensity $\leq 200 \mu \mathrm{mol} \mathrm{m}-2$ $\mathrm{s}-1.52$ Amount of nitrate content present per serving of any vegetable is non-toxic but its metabolites and bi products such as nitrite, nitric oxide and $\mathrm{N}$-nitrous compounds are the main compounds of health concern. ${ }^{53}$ Dietary intake of total nitrate undergoes enterosalivary circulation, which is then converted into nitrites by oral bacteria and salivary enzymes. This conversion rate is about $5-7 \%$ in healthy adults but considerably higher in infants and patients with gastroenteritis. ${ }^{54}$ The presence of nitrates in infants' causes very serious disease called methemoglobinemia or 'blue baby syndrome' leading to suffocation and death..$^{55}$ The World Health Organization has set the acceptable daily intake of nitrate at $3.7 \mathrm{mg} / \mathrm{kg}$ body weight and nitrite at $0.06 \mathrm{mg} /$ $\mathrm{kg}$ body weight. ${ }^{56}$ In addition, the European Commission Regulation number 1881/2006 (EC, 2006) established the thresholds of nitrates in spinach at $2500-3500 \mathrm{mg} / \mathrm{kg}$ fresh weight, lettuce at $3000-5000 \mathrm{mg}$ / $\mathrm{kg}$ fresh weight, and lettuce type 'Iceberg' at $2000-2500 \mathrm{mg} / \mathrm{kg}$ fresh weight. ${ }^{52}$ Analytical methods for the quantification of nitrates and nitrites present in food is the colorimetric method, ${ }^{57}$ photometric, ${ }^{58}$ potentiometricassay, ${ }^{59}$ Capillary electrophoresis, ${ }^{60}$ HPLC $^{61}$ with UV/DAD detection ${ }^{62}$ or post-column derivatisation. ${ }^{63}$ It can also be determined using IC coupled with mass spectrometry ${ }^{64}$ and flow injection analysis. ${ }^{65}$

Oxalates: Oxalic acid $\left[(\mathrm{COOH})_{2}\right]$ in combination with its salts or minerals form oxalates. Oxalic acid is present in the cell sap of many of the green leafy vegetable. ${ }^{66}$ Depending on plant species, oxalates can occur as insoluble salts of calcium, magnesium and iron, and soluble salts of potassium and sodium or as a combination of these two forms. ${ }^{67}$ However, oxalic acid does not interfere with zinc absorption and metabolism. ${ }^{68}$ Insoluble oxalates are excreted in faces. Whereas, soluble oxalates affect the human body by forming a strong chelate with dietary calcium and other minerals rendering the complex unavailable for absorption and assimilation. This insoluble calcium oxalate in the crystal form is stored in the kidney causing serious health-related problem called kidney stone. ${ }^{69}$ The adverse effect of calcium absorption is higher when the ratio of oxalate: calcium is more than 9:4. ${ }^{67}$ Besides dietary intake, oxalates are also formed in the human body as the by-product of ascorbic acid and glyoxylate metabolism. ${ }^{70}$ The distribution of oxalic acid is uneven in plants and varies among species. Generally, the amount of oxalate is high in leaves followed by seeds and less in stems.$^{71}$ Hence, consumption of leafy vegetables has more of a concern when there is a risk of high oxalic acid concentration. Reports show leaves of amaranth, rhubarb (Rheum rhabarbarum), spinach and beet (Beta vulgaris) have more oxalate levels than in their stems. ${ }^{67}$ The various methods employed in the determination of oxalate in plant leaf tissues are enzymatic analysis. ${ }^{72-74}$ But this method of analysis in plants interferes with the carbohydrates in the plant tissue. ${ }^{75}$ Other methods are HPLC, ${ }^{76,77}$ titration, ${ }^{78}$ capillary and gas chromatography. ${ }^{79}$

Tannins: The word tannin was coined by Seguin (1976) to mean substances present in vegetable extracts and are responsible for converting animal skin into leather products. Vegetable tannins are polyphenols with relatively high molecular weight (up to 20,000 Da) and can form complexes with carbohydrates and proteins in aqueous solutions..$^{80}$ Plant tannins are present in plant bark, wood, fruits, fruit pods, leaves, roots and plant galls. ${ }^{81,82}$ Gupta \& Haslam ${ }^{83}$ further explained that vegetable tannins are normal metabolic products and are not the products of in vitro transformation by chemical or other means. Freudenberg ${ }^{84}$ classified tannins into two groups based on the structural types, namely; hydrolysable tannins and non-hydrolysable or condensed tannins. This is the most widely accepted classification. Of the two groups, condensed tannins are abundantly found in higher plants (e.g., proanthocyanidins). The hydrolysable tannins consist of glucose surrounded by phenolic acids and are readily hydrolyzed by acids, bases and certain enzymes. These condensed tannins are oligomers, which resist hydrolysis. ${ }^{85}$ Vegetable tannins are water soluble phenolics compounds that are widely distributed in the plant kingdom. Tannins can produce undesirable effects in food when present in considerably high amounts. Tannins have ability to form a complex with proteins through hydrogen bonding and covalent linkages. This results in the precipitation of proteins to make it unavailable for absorption. ${ }^{85}$ Incidence of esophagus cancer is linked with dietary tannins. ${ }^{86,87}$ No method has been found completely satisfactory due to the complex nature of phenolic compounds. However, Vanillin assay, ${ }^{88}$ HPLC coupled with MS ${ }^{89}$ and UV spectroscopes ${ }^{90}$ are some of the methods for determination of tannins.

Phytic acid: Phytic acid (i.e. myo-inositol hexaphosphoric acid) is a natural substance that acts as a major storage of phosphorus in all leafy vegetables. ${ }^{91}$ Phytic acid is found in plant tissues as salts of cations such as potassium, magnesium and calcium. Significant number of negatively charged phosphate groups in phytic acid chelate essential mineral nutrients in human body making it less available for absorption. ${ }^{92}$ Phytates has negative impact on the activity of digestive enzymes and act through chelation of mineral cofactors or interaction with protein. For instance, phytate interferes with zinc homeostasis. Protein binding by phytate can be direct (phytate: protein) or indirect (through a cation bridge). ${ }^{93}$ Processing techniques such as boiling and cooking have no effect in reducing the level of phytic acid as the phytate is relatively heat stable. ${ }^{94}$ However, evidence showed that although food preparation techniques help in reducing the phytic acid level, the most effective methods are lactic acid fermentation and soaking in acid medium. ${ }^{95}$ The main method for phytic acid determination in food samples was developed by Wade \& Morgan ${ }^{96}$ after whom various methods were developed. Current methods found in the literature are complexometric titration, ${ }^{97}$ enzymatic reaction, ${ }^{98}$ potentiometric ${ }^{99}$ and ionic chromatography. ${ }^{100}$

Cyanogenic glycosides: Cyanogenic glycosides $(\mathrm{CN})$ are derivatives of amino acids, and a group of secondary metabolites present in 
more than 2500 plant species. ${ }^{101}$ Chemically, cyanogenic glycosides are described as the glycosides of $\alpha$-hydroxinitriles. Amygdalin is the first isolated cyanogenic glycosides as a product of hydrolysis from seeds of bitter almond (Amygdalus communis) by Pierre Jean Robiquet and Antoine-Francois Boutron-Chalardin 1802. ${ }^{102}$ Most plants are known to produce small quantity of cyanide along with ethylene production. ${ }^{103}$ Cyanogenic glycosides have received much research consideration because of the known poisoning nature of hydrogen cyanide $(\mathrm{HCN})$. Its presence in economically important crops such as cassava, durian (Durio zibethinus), white clover (Trifolium repens) and many other cultivated plants species has been of great concern and research attention. ${ }^{101}$ Cassava is the staple food in many African and Latin American countries ${ }^{104}$ where not only the root tubers but the leaves are also eaten as green leafy vegetable. ${ }^{12}$ It is therefore, common to report on cassava poisoning in many of these countries. For instance, acute cassava poisoning has been reported in Nigeria since the late 1980s. ${ }^{105}$ Kwashiorkor is the most serious problem prevailing in areas where cassava is largely consumed as staple food due to the presence of cyanogenic glycosides that hinders protein absorption in humans. ${ }^{101}$ According to Kamalu, ${ }^{106}$ inhibition of Na-K-ATPase is caused by the absorption of linamarin in cassava diet. This results in electrolyte imbalance with $\mathrm{K}$ depletion. Some of the methods to determine cyanogenic glycosides are gas-liquid chromatography, ${ }^{107}$ ultra-high-performance liquid chromatography ${ }^{108}$ coupled with a mass spectrometer, a reversed-phase high-performance liquid chromatography ${ }^{109}$ and HPLC. ${ }^{110}$

\section{Processing methods to reduce anti nutrients}

Heat treatment is the most effective method to reduce the antinutrition factors present in green leafy vegetables so far. ${ }^{111}$ Cooking and blanching helps in the removal of anti nutrients through rupturing the plant cell wall followed by leaching out of soluble compounds into the blanching medium. The levels of phytic acid and oxalic acid can be effectively reduced by cooking and blanching methods. ${ }^{112}$ However, this practice could also lead to the leaching out of nutritional elements. ${ }^{113}$ A study conducted on leaves of amaranth (Amaranthus tricolor), bathua (Chenopodium album), fenugreek (Trigonella foenum grecum) and spinach (Spinacia oleracia) for reducing anti nutrients reported blanching alone between 10 and 15 minutes resulted in significant reduction in phytic acid. Oxalic acid content was reduced by both blanching and cooking whereas drying and storage did not significantly affect anti-nutrition factors in green leafy vegetables. ${ }^{114-116}$

\section{Conclusion}

Green leafy vegetables provide vital nutrients required for human health and wellbeing. These include amino acids, vitamins, essential fatty acids, minerals and dietary fiber. It also has significant socioeconomic benefits. For instance, farmers in the tropics and subtropics, mostly women, grow and harvest green leafy vegetables to supplement household income. In rural areas, traditional leafy vegetables play important role as nutritional source, and it is available all-year. Green leafy vegetables are usually considered as the cheapest source of food for vitamins and micronutrients supplementation to combat nutrients deficiencies. It is also used as herbal and medicinal plants in various cultural and traditional settings for many different ailments. The presence of anti nutritional factors such as nitrates, oxalates, phytates, cyanogenic glycosides and tannins in green leafy vegetables can affect micronutrients absorption and thus, make the latter unavailable. Thermal processing of leafy vegetables through boiling, cooking and blanching before consumption help in reducing the level of anti nutrients. There is a scope for research to identify and explore the potential of edible leaves of indigenous and underexploited plants for use as food and medicine, and inclusion in mainstream agri-food systems. Research is also needed to explore different varieties and possibility of adopting agronomic practices that will reduce the concentration and effect of anti-nutritional factors in green leafy vegetables and enhance their nutritive value.

\section{Acknowledgements}

Financial support was obtained from The Vitamin Scholarship to Nishchitha Hemmige Natesh. The authors would like to thank the lab group members of Compost science and Bio stimulant Lab for support.

\section{Conflict of interest}

The author declares no conflict of interest.

\section{References}

1. Shukla P, Kumar R, Raib AK. Detection of minerals in green leafy vegetables using laser induced breakdown spectroscopy. Journal of Applied Spectroscopy. 2016;83(5):872-877.

2. Da Silva Dias João Carlos, Imai S. Vegetables consumption and its benefits on diabetes. Journal of Nutritional Therapeutics. 2017;6(1):110.

3. Grusak MA, Della Penna D. Improving the nutrient composition of plants to enhance human nutrition and health. Annu Rev Plant Physiol Plant Mol Biol. 1999;50(1):133-161.

4. Nath P, Gaddagimath PB, Dutta O. Food and nutrition security and vegetables: A Global Perspective. Prem Nath Agricultural Science Foundation, India; 2004. p. 1-412.

5. Fresco Louisce O, Baudoin Wilfried O. Food and Nutrition Security towards Human Security, Food Security and Vegetables-A Global Perspective, P.N. Agricultural Science Foundation, Bangalore, India; 2004. p. 7-42.

6. Dias JS. Major classes of phytonutriceuticals in vegetables and health benefits: A review. Journal of Nutritional Therapeutics. 2012;1(1):3162 .

7. Iheshiulo EM, Abbey L, Asiedu SK. Response of kale to single-dose application of $\mathrm{K}$ humate, dry vermicasts, and volcanic minerals. International Journal of Vegetable Science. 2017;23(2):135-144.

8. Bian ZH, Yang QC, Liu WK. Effects of light quality on the accumulation of phytochemicals in vegetables produced in controlled environments: A review. J Sci Food Agric. 2015;95(5):869-877.

9. Odhav B, Beekrum S, Akula U, et al. Preliminary assessment of nutritional value of traditional leafy vegetables in KwaZulu-Natal, South Africa. Journal of Food Composition and Analysis. 2007;20(5):430-435.

10. Lee SK, Kader AA. Preharvest and postharvest factors influencing vitamin C content of horticultural crops. Postharvest Biology and Technology. 2000;20(3):207-220.

11. Zhang B, Wijesundara NM, Abbey L, et al. Growing medium amendments effect on growth, secondary metabolites and anti-streptococcal activity of two species of Plectranthus. Journal of Applied Research on Medicinal and Aromatic Plants. 2017;5:53-59.

12. Uusiku NP, Oelofse A, Duodu KG, et al. Nutritional value of leafy vegetables of sub-Saharan Africa and their potential contribution to human health:A review. Journal of Food Composition and Analysis. 2010;23(6):499-509. 
13. Aletor O, Oshodi A, Ipinmoroti K. Chemical composition of common leafy vegetables and functional properties of their leaf protein concentrates. Food Chemistry. 2002;78(1):63-68.

14. Kawashima Nobumaro, Wildman SG. Fraction I protein. Annual Review of Plant Physiology. 1970;21(1):325-358.

15. Edelman M, Colt M. Nutrient value of leaf vs. seed. Front Chem. 2016;4:1-32.

16. Fasuyi AO. Nutrient composition and processing effects on cassava leaf (Manihotesculenta crantz) anti nutrients. Pakistan Journal of Nutrition. 2005;4(1):37-42.

17. Kalogeropoulos N, Chiou A, Ioannou M, et al. Nutritional evaluation and bioactive micro constituents (phytosterols, tocopherols, polyphenols, triterpenic acids) in cooked dry legumes usually consumed in the Mediterranean countries. Food Chemistry. 2010;121(3):682-690.

18. Odhav B, Beekrum S, Akula U, et al. Preliminary assessment of nutritional value of traditional leafy vegetables in KwaZulu-Natal, South Africa. Journal of Food Composition and Analysis. 2007;20(5):430-435.

19. Gibson RS, Perlas L, Hotz C. Improving the bioavailability of nutrients in plant foods at the household level. Proc Nutr Soc. 2006;65(2):160-168.

20. AOAC. Official methods of analysis. 15th ed. In: Helrich K, editor. USA: Association of Official Analytical Chemists; 1990.

21. Gopalan C, Ramasastri B, Balasubramanian S. Proximate principles: Common foods. Nutritive Value of Indian Foods (Revised and Updated Edition). Hyderabad, India: National Institute of Nutrition, ICMR, India; 2000. p. 53-55.

22. Jenkins DJ, Kendall CW, Popovich DG, et al. Effect of a very-highfiber vegetable, fruit, and nut diet on serum lipids and Colonic function. Metabolism. 2001;50(4):494-503.

23. National Research council. Recommended dietary allowances. USA: National Academy Press; 1989. p. 1-285.

24. Roberfroid M. Dietary fiber, inulin, and oligofructose: A review comparing their physiological effects. Crit Rev Food Sci Nutr. 1993;33(2):103-148.

25. Spiller G. Dietary fiber in prevention and treatment of disease. CRC Handbook of Dietary Fiber in Human Nutrition. USA: CRC Press LLC; 2001. p. 363-431.

26. Britton G. Carotenoids. In: Hendry GAF, et al, editors. Natural food colorants, Springer, USA; 1996. p. 197-243.

27. Trumbo P, Yates AA, Schlicker S, et al. Dietary reference intakes: Vitamin A, vitamin $\mathrm{K}$, arsenic, boron, chromium, copper, iodine, iron, manganese, molybdenum, nickel, silicon, vanadium, and zinc. J Am Diet Assoc. 2001;101(3):294-301

28. Baudoin WO, Louise Fresco O. Food and nutrition security towards human security. ICV Souvenir Paper, Italy; 2002. p. 1-19.

29. Cheynier V. Polyphenols in foods are more complex than often thought. Am J Clin Nutr. 2005;81(1S):223S-229S.

30. Raju M, Varakumar S, Lakshminarayana R, et al. Carotenoid composition and vitamin A activity of medicinally important green leafy vegetables. Food Chemistry. 2007;101(4):1598-1605.

31. Jiménez Aguilar DM, Grusak MA. Minerals, vitamin C, phenolics, flavonoids and antioxidant activity of Amaranthus leafy vegetables. Journal of Food Composition and Analysis. 2017;58:33-39.

32. Moll R, Davis B (2017) Iron, vitamin $B_{12}$ and folate. Medicine 45(4): 198 203.

33. Castorena Torres F, Ramos Parra PA, Hernández Méndez RV, et al Natural folates from biofortified tomato and synthetic 5-methyltetrahydrofolate display equivalent bioavailability in a murine model Plant Foods Hum Nutr. 2014;69(1):57-64.
34. FAO W. Human vitamin and mineral requirements. Report of a Joint FAO/WHO Expert Consultation, Bangkok, Thailand. Food and Nutrition Division, FAO, Rome, Italy; 2001. p. 1-303.

35. Saini R, Manoj P, Shetty N, et al. Relative bioavailability of folate from the traditional food plant Moringa oleifera L. as evaluated in a rat model. J Food Sci Technol. 2016;53(1):511-520.

36. Santos J, Mendiola J, Oliveira M, et al. Sequential determination of fatand water-soluble vitamins in green leafy vegetables during storage. $J$ Chromatogr A. 2012;1261:179-188.

37. Baudoin WO, Louise Fresco O. Food and nutrition security towards human security. ICV Souvenir Paper, Italy; 2002. p. 1-19.

38. Galloway R. Anemia prevention and control: What works part I: Program guidance, USA; 2003. p. 1-77.

39. Welch RM. Zinc concentrations and forms in plants for humans and animals. Developments in Plant and Soil Sciences. 1993;55:183-195.

40. Kumari M, Gupta S, Lakshmi AJ, et al. Iron bioavailability in green leafy vegetables cooked in different utensils. Food Chemistry. 2004;86(2):217-222.

41. Kala A, Prakash J. Nutrient composition and sensory profile of differently cooked green leafy vegetables. International Journal of Food Properties. 2004;7(3):659-669.

42. AOAC. Official methods of analysis. Latimer JW, et al, editors. USA 2005.

43. Hamazaki T, Okuyama H. Fatty acids and lipids-New findings. Karger Medical and Scientific Publishers, Japan; 2001. p. 1-53.

44. Simopoulos AP. Omega-3 fatty acids in wild plants, nuts and seeds. Asia Pacific Journal of Clinical Nutrition. 2002;11(s6):S163-S173.

45. Simopoulos AP, Norman HA, Gillaspy JE. Purslane in human nutrition and its potential for world agriculture. World Rev Nutr Diet. 1995;77:4774

46. Guil Guerrero JL, Torija Isasa ME. Fatty acid profiles of Mediterranean wild edible plants. In: Sánchez Mata M, et al, editors. Mediterranean wild edible plants, Springer, USA; 2016. p. 173-186.

47. Dagostin JLA. Use of blanching to reduce anti nutrients, pesticides, and microorganisms. In: Richter Reis F, editor. New perspectives on food blanching, Springer, USA; 2017. p. 61-94.

48. Rosenthal G, Janzen D. Herbivores: Their interaction with plant secondary metabolites. 2nd ed. Science direct, USA; 1979. p. 1-718.

49. Cheeke P, Shull L. Natural toxicants in feeds and livestock. West Port AVI Publishing Inc, USA; 1985.

50. Tamme T, Reinik M, Roasto M, et al. Nitrate in leafy vegetables, culinary herbs, and cucumber grown under cover in estonia: Content and intake. Food Addit Contam Part B Surveill. 2010;3(2):108-113.

51. Santamaria P. Nitrate in vegetables: Toxicity, content, intake and EC regulation. Journal of the Science of Food and Agriculture. 2006;86(1):10-17.

52. Colonna E, Rouphael Y, Barbieri G, et al. Nutritional quality of ten leafy vegetables harvested at two light intensities. Food Chem. 2016;199:702710 .

53. Parks S, Huett D, Campbell L, et al. Nitrate and nitrite in Australian leafy vegetables. Australian Journal of Agricultural Research. 2008;59(7):632-638.

54. Bruning Fann CS, Kaneene JB. The effects of nitrate, nitrite and Nnitroso compounds on human health: A review. Vet Hum Toxicol. 1993;35(6):521-538. 
55. Majumdar D. The blue baby syndrome: Nitrate poisoning in humans Resonance. 2003;8(10):20-30.

56. Alexander J, Benford D, Cockburn A, et al. Nitrate in vegetables scientific opinion of the panel on contaminants in the food chain. EFSA J. 2008;689:1-79.

57. Onyesom I, Okoh P. Quantitative analysis of nitrate and nitrite contents in vegetables commonly consumed in delta state, Nigeria. $\mathrm{Br} J$ Nutr. 2006;96(5):902-905.

58. Sušin J, Kmecl V, Gregorčič A. A survey of nitrate and nitrite content of fruit and vegetables grown in slovenia during 1996-2002. Food Addit Contam. 2006;23(4):385-390.

59. Tamme T, Reinik M, Roasto M, et al. Nitrate in leafy vegetables, culinary herbs, and cucumber grown under cover in estonia: Content and intake. Food Addit Contam Part B Surveill. 2010;3(2):108-113.

60. Merusi C, Corradini C, Cavazza A, et al. Determinationof nitrates, nitrites and oxalates in food products by capillary electrophoresis with $\mathrm{P}^{\mathrm{H}}$ dependent electro osmotic flow reversal. Food Chemistry. 2010;120(2):615-620.

61. Thomson B, Nokes C, Cressey P. Intake and risk assessment of nitrate and nitrite from New Zealand foods and drinking water. Food Addit Contam. 2007;24(2):113-121.

62. Ferreira I, Silva S. Quantification of residual nitrite and nitrate in ham by reverse-phase high performance liquid chromatography/diode array detector. Talanta. 2008;74(5):1598-1602

63. Casanova JA, Gross LK, Mc Mullen SE, et al. Use of Griess reagen containing vanadium (III) for post-column derivatisation and simultaneous determination of nitrite and nitrate in baby food. $J$ AOAC Int. 2006;89(2):447-451.

64. Saccani G, Tanzi E, Cavalli S, et al. Determination of nitrite, nitrate, and glucose- 6 -phosphate in muscle tissues and cured meat by IC/MS. $J$ AOAC Int. 2006;89(3):712-719.

65. Ruiz Capillas C, Jimenez Colmenero F. Determination of preservatives in meat products by flow injection analysis (FIA). Food Additives and Contaminants. 2008;25(10):1167-1178.

66. Champ MM. Non-nutrient bioactive substances of pulses. Br J Nutr 2002;88(S3):S307-S319.

67. Noonan S, Savage G. Oxalate content of foods and its effect on humans. Asia Pac J Clin Nutr. 1999;8(1):64-74.

68. Welch RM, House WA, Van Campen D. Effects of oxalic acid on availability of zinc from spinach leaves and zinc sulfate to rats. $J$ Nutr 1977;107(6):929-933

69. Radek M, Savage G. Oxalates in some Indian green leafy vegetables. In J Food Sci Nutr. 2008;59(3):246-260.

70. Williams HE, Wandzilak TR. Oxalate synthesis, transport and the hyperoxaluric syndromes. J Urol. 1989;141(3):742-747.

71. Osweiler GD, Carson TL, Buck WB, et al. Clinical and diagnostic veterinary toxicology. Kendall/Hunt Publishing Company, USA; 1985. p. $1-494$.

72. Kasidas GP, Rose GA. Oxalate content of some common foods: Determination by an enzymatic method. J Hum Nutr. 1980;34(4):255266

73. Chai W, Liebman M. Oxalate content of legumes, nuts, and grain-based flours. Journal of Food Composition and Analysis. 2005;18(7):723-729.

74. Okombo J, Liebman M. Oxalate content of selected breads and crackers. Journal of Food Composition and Analysis. 2010;23(1):118-121.

75. Zarembski PM, Hodgkinson A. The determination of oxalic acid in food Analyst. 1962;87(1038):698-702.
76. Savage G, Vanhanen L, Mason S, et al. Effect of cooking on the soluble and insoluble oxalate content of some New Zealand foods. Journal of Food Composition and Analysis. 2000;13(3):201-206.

77. Yu L, Peng X, Yang C, et al. Determination of oxalic acid in plan tissue and root exudates by reversed phase high performance liquid chromatography. Chinese Journal of Analytical Chemistry. 2002;30(9):1119-1122.

78. Baker C. The determination of oxalates in fresh plant material. Analyst. 1952;77(916):340-344

79. Ohkawa H. Gas chromatographic determination of oxalic acid in foods J Assoc Off Anal Chem. 1985;68(1):108-111.

80. Khanbabaee K, Van Ree T. Tannins: Classification and definition. Nat Prod Rep. 2001;18(6):641-649.

81. Mané C, Sommerer N, Yalcin T, et al. Assessment of the molecular weight distribution of tannin fractions through MALDI-TOFMS analysis of protein-tannin complexes. Anal Chem. 2007;79(6):2239-2248.

82. Ricci A, Olejar KJ, Parpinello GP,et al. Application of Fourier transform infrared (FTIR) spectroscopy in the characterization of tannins. Applied Spectroscopy Reviews. 2015;50(5):407-442.

83. Gupta R, Haslam E. Vegetable tannins: Structure and biosynthesis. Pape presented at the Polyphenols in Cereals and Legumes: Proceedings of a Symposium, UK; 1980.

84. Freudenberg K, Weinges K. Catechins and flavonoid tannins. The Chemistry of Flavonoid Compounds. 1962. p. 197-216.

85. Salunkhe DK, Chavan J. Dietary tannins: Consequences and remedies USA: CRC Press; 1989. p. 1-208.

86. Bate Smith EC. Phytochemistry of proanthocyanidins. Phytochemistry 1975;14(4):1107-1113.

87. Harborne J. The biochemical systematics of flavonoids. In: Harborne JB, et al, editors. The flavonoids, Springer, USA; 1975. p. 1056-1095.

88. Price ML, Butler LG. Rapid visual estimation and spectro photometric determination of tannin content of sorghum grain. J Agric Food Chem 1978;25(6):1268-1273.

89. Lazarus SA, Adamson GE, Hammerstone JF, et al. High performance liquid chromatography/mass spectrometry analysis of proanthocyanidins in foods and beverages. J Agric Food Chem. 1999;47(9):3693-3701.

90. Dos Santos Grasel F, Ferrão MF, Wolf CR. Ultraviolet spectroscopy and chemo metrics for the identification of vegetable tannins. Industrial Crops and Products. 2016;91:279-285.

91. Harland BF, Oberleas D. Phytate in foods. Energy. Nutrition of women, Karger Publishers, Japan; 1987. p. 235-259.

92. Reddy NR, Shridhar Sathe K. Occurrence, distribution, content, and dietary intake of phytate. 1st edition. Food Phytates. USA: CRC Press; 2001. p. 1-280.

93. Ravindran V, Selle P, Bryden W. Effects of phytase supplementation, individually and in combination, with glycanase, on the nutritive value of wheat and barley. Poult Sci. 1999;78(11):1588-1595.

94. Ryden P, Selvendran R. Phytic acid: Properties and determination Encyclopedia of Food Science, Food Technology and Nutrition. UK: Academic Press; 1993. p. 3582-3587.

95. Gupta RK, Gangoliya SS, Singh NK. Reduction of phytic acid and enhancement of bioavailable micronutrients in food grains. J Food Sci Technol. 2015;52(2):676-684.

96. Wade HE, Morgan DM. Fractionation of phosphates by paperionophoresis and chromatography. Biochem J. 1955;60(2):264-270. 
97. Burgos Luján I, Tong AZ. Determination of phytic acid in juices and milks by developing a quick complexometric-titration method. Food Analytical Methods. 2015;8(7):1836-1841.

98. Vieira EC, Nogueira ARA. Orthophosphate, phytate, and total phosphorus determination in cereals by flow injection analysis. J Agric Food Chem. 2004;52(7):1800-1803.

99. Yang F, Zhang C, Liu Q, et al. Ca 2 -selective electrode: A simple method to measure the phytase-aided release of bound calcium in soymilk. Journal of Food Composition and Analysis. 2015;39:43-47.

100. Rugova A, Puschenreiter M, Santner J, et al. Speciation analysis of orthophosphate and myo-inositol hexakisphosphate in soil and plantrelated samples by high-performance ion chromatography combined within ductively coupled plasma mass spectrometry. J Sep Sci. 2014;37(14):1711-1719.

101. Vetter J. Plant cyanogenic glycosides. Toxicon. 2000;38(1):11-36.

102. Vetter J. Plant cyanogenic glycosides. Plant Toxins. 2017:287-317.

103. Mc Mahon JM, White WL, Sayre RT. Cyanogenesis in cassava (Manihotesculenta crantz). Journal of Experimental Botany. 1995;46(228):731-741.

104. Boccas B. Le manioc, plante vivrière de première importance dans le monde tropical $=$ cassava, staple food crop of prime importance in the tropics. Le Courrier. Afrique-Caraïbes-Pacifique-Communauté Européenne. 1987;(101):72-73.

105. Akintonwa A, Tunwashe O, Onifade A. Fatal and non-fatal acute poisoning attributed to cassava-based meal. ISHS Acta Horticulturae 375, Belgium; 1994. p. 285-288.

106. Kamalu BP. Cassava (Manihot esculenta crantz) in the etiology of kwashiorkor. Nutrition Research Reviews. 1993;6(1):121-135.

107. Bacala R, Barthet V. Development of extraction and gas chromatography analytical methodology for cyanogenic glycosides in flaxseed (Linum usitatissimum). J AOAC Int. 2007;90(1):153-161.
108. Shlichta JG, Glauser G, Benrey B. Variation in cyanogenic glycosides across populations of wild lima beans (Phaseolus lunatus) has no apparent effect on bruchid beetle performance. J Chem Ecol. 2014;40(5):468-475.

109. Sakalem ME, Negri G, Tabach R. Chemical composition of hydroethanolic extracts from five species of the Passiflora genus. Rev bras farmacogn. 2012;22(6):1219-1232.

110. Berenguer Navarro V, Giner Galván R, Grané Teruel N, et al. Chromatographic determination of cyanoglycosides prunasin and amygdalin in plant extracts using a porous graphitic carbon column. $J$ Agric Food Chem. 2002;50(24):6960-6963.

111. Mosha T, Gaga H. Nutritive value and effect of blanching on the trypsin and chymotrypsin inhibitor activities of selected leafy vegetables. Plant Foods for Human Nutrition. 1999;54(3):271-283.

112. Oboh G. Effect of blanching on the antioxidant properties of some tropical green leafy vegetables. LWT-Food Science and Technology. 2005;38(5):513-517.

113. Mepba H, Eboh L, Banigo D. Effects of processing treatments on the nutritive composition and consumer acceptance of some Nigerian edible leafy vegetables. African Journal of Food, Agriculture, Nutrition and Development. 2007:7(1).

114. Yadav SK, Sehgal S. Effect of domestic processing and cooking on selected anti nutrient contents of some green leafy vegetables. Plant Foods for Human Nutrition. 2003;58(3):1-11.

115. 2015-2020 Dietary Guidelines for Americans. 8th ed. USA; 2015. p. $1-144$.

116. Ramulu P, Rao PU. Total, insoluble and soluble dietary fiber contents of Indian fruits. Journal of Food Composition and Analysis. $2003 ; 16(6): 677-685$. 